\title{
Anti-diabetic effects of Allium tuberosum rottler extracts and lactic acid bacteria fermented extracts in type 2 diabetic mice model
}

\author{
Bae Jin Kim, Seung Kyeung Jo, Yoo Seok Jeong, Hee Kyoung Jung* \\ Biohealth Convergence Center, Daegu Technopark, Daegu 704-801, Korea
}

\section{제2형 당뇨질환모델 $d b / d b$ 마우스에서 부추 추출물 및 유산균 발효물의 항당뇨 효과}

\author{
김배진 · 조성경 · 정유석 · 정희경* \\ (재) 대구테크노파크 바이오헬스융합센터
}

\begin{abstract}
The anti-diabetic effects of Allium tuberosum Rottler extracts (ATE) and ATE fermented with lactic acid bacteria in $d b / d b$ mice were evaluated. The electron donating activity of ATE fermented with Lactobacillus plantarum, and Lactobacillus casei, respectively, increased compared to that of ATE, but the superoxide radical scavenging activity of the ATE incubated with $L$. plantarum decreased. The superoxide radical scavenging activity of the ATE fermented with both $L$. plantarum and $L$. casei was similar to that of the ATE. Therefore, fermented ATE (FATE) was prepared for in vivo testing by incubating it with both $L$. plantarum and $L$. casei. The $d b / d b$ mice were divided into six groups: normal (non-diabetic mice), diabetic control (DM), and four experimental groups administered 200 or $400 \mathrm{mg} / \mathrm{kg} / \mathrm{day}$ ATE (ATE200 and ATE400) and 200 or $400 \mathrm{mg} / \mathrm{kg} / \mathrm{day}$ FATE (FATE200 and FATE400). Weight gain was significantly inhibited in the FATE200 group compared with that in the other $d b / d b$ mice groups $(p<0.05)$. The areas under the curve of the ATE400 and FATE400 groups were significantly smaller than that of the DM group in the glucose tolerance evaluation. The serum glucagon-like peptide-1 levels in the ATE400 and FATE400 groups increased. These results indicate that administering ATE and FATE may be effective against anti-hyperglycemia by regulating insulin resistance. In particular, FATE may be beneficial for controlling obesity in type 2 diabetes.
\end{abstract}

Key words : Allium tuberosum rottler, $d b / d b$ mouse, oral glucose tolerance test, insulin resistance, type 2 diabetes mellitus

\section{서 론}

오늘날 현대사회는 경제적 풍요와 함께 식생활이 서구화 되고 과다한 영양 섭취 및 신체활동량의 감소로 인해 비만, 고지혈증, 대장암, 당뇨병과 같은 만성대사질환의 발병율 이 증가되고 있다(1). 특히, 당뇨병은 세계 3대 위험 질환

*Corresponding author. E-mail : zangone@ttp.org

Phone : 82-53-602-1880, Fax : 82-53-602-1898

Received 31 October 2014; Revised 12 January 2015; Accepted 26 January 2015.

Copyright (c) The Korean Society of Food Preservation. All rights reserved.
중 하나로써 '2012년 사망원인통계'에 의하면 당뇨병은 암, 심장질환, 뇌혈관 질환, 고의적 자해에 이어 우리나라 국민 의 사망요인 중 5 위를 차지하고 있다(2). 당뇨병은 췌장에 있는 langerhans섬계가 손상되면 이들의 균형이 파괴되어 산화 스트레스가 발생하게 된다(3-7). 당뇨병에서의 과도한 당화반응은 항산화 체계의 손상으로 인해 산화적 스트레스 가 증가되는 것으로 보고된 바 있다(8). 현재 당뇨병 치료 및 개선제로 많이 사용되는 제제는 insulin 분비 촉진제, insulin 저항성 개선제, insulin 주사제 등이 대표적이다. 이 러한 제제들은 혈당 저하 효과가 뛰어난 장점이 있으나, 장기간 사용 시 저혈당 유발, 체지방 증가, 간 독성, insulin 저항성 증가 등과 같이 다양한 부작용을 유발한다 $(9,10)$. 
이에 따라 당뇨병의 치료 및 개선을 위하여 부작용이 적은 천연물에 대하여 관심이 높아지고 있는 실정이다. 하지만 천연물 소재의 효능은 대부분 구전되어진 것으로 과학적인 근거가 부족한 문제점이 있다. 최근에는 항당뇨 효능이 기 대되는 천연물 소재로 밀순 물 추출물(11), 옥수수수염 물 추출물(12), 대두 및 청국장 분말(13) 등이 보고된 바 있다.

부추(Allium tuberosum Rottler)는 국내뿐만 아니라 동북 아시아 전역에 분포하고 있는 백합과의 다년초로써 독특한 맛과 향기가 있어 식생활에 많이 사용되며 한방에서는 보 혈, 청혈, 구충, 이뇨, 건위, 건뇌, 강심, 진통, 해독 등의 약재로 이용되고 있다(14). 또한 부추의 생리활성과 관련하 여 항암(15), 항균(16), 항산화(17) 등에 효능이 있는 것으로 연구된 바 있으나, 아직 기능성 소재로서 산업적 활용은 미비한 실정이다.

발효는 예전부터 행해져온 가공 방법의 하나로써 유익한 미생물의 작용을 통해 천연물이 가진 유용성분 및 영양성을 증진시키는 장점이 있다(18). 특히 발효에 많이 이용되는 유산균은 인간이 이용할 수 있는 가장 유익한 미생물로써 발효 식품에서 의약품에 이르기까지 광범위하게 활용되고 있다. 유산균의 주요 대사산물은 lactic acid인데 이것은 $\mathrm{pH}$ 를 급격히 강하시킴으로써 부패균의 생장을 억제하고 불용 성 무기성분을 가용화하는 작용을 한다(19). 또한 유산균 발효는 식품의 기능성을 증가시키기도 하는데 Park 등(20) 은 Lactobacillus delbrueckii와 Bifidobacterium breve로 발효 시킨 홍삼을 당뇨 쥐에 투여 시 미발효 홍삼보다 혈당 저하 에 있어 더 효과적임을 보고하였다.

대구의 부추 생산은 달성군 다사면을 중심으로 년 5,465 톤 정도 생산하고 있으나 평균적으로 $11 \sim 16 \%$ 정도의 폐기 율을 보이고 있어 비상품 부추가 다량 발생하고 있다. 따라 서 본 연구에서는 비상품 부추의 산업적 활용과 경제성을 증대시키고자 제 2 형 당뇨병 실험동물 모델인 $d b / d b$ mice에 서 부추 추출물 및 부추 발효물의 항당뇨에 대한 영향을 조사하여 기능성 소재로서의 활용 가능성을 타진하고자 하였다.

\section{재료 및 방법}

\section{부추 추출물 및 부추 발효물의 제조}

본 실험에 사용된 부추는 대구광역시 달성군 박곡 지역 농가에서 생산된 부추를 사용하였다. 부추 추출물은 부추 중량 대비 10 배의 물을 가하고 추출기(KSNP B1130, KyungSeo Machines, Incheon, Korea)에서 $65^{\circ} \mathrm{C}$, 3시간 1회 추출한 다음 여과지에 여과한 액을 사용하였다. 부추 발효 물 제조를 위한 유산균은 식품의약품안전처에서 제공하는 식품원재료 데이터 베이스에 근거하여 식용이 가능한 Lactobacillus acidophilus(KCTC 3151, L. acidophilus),
Lactobacillus casei(KCTC 13086, L. case1), Lactobacillus plantarum(KCTC 3104, L plantarum)을 한국생명공학연구 원 미생물자원센터에서 분양받아 본 실험에 이용하였다. 부추 발효를 위한 유산균 전배양액은 MRS 배지(Becton, Dickinson and Company, Franklin Lakes, NJ, USA) $5 \mathrm{~mL}$ 에 각 유산균을 백금이를 이용하여 접종하고 $37^{\circ} \mathrm{C}$ 배양기 (VS-8480, Vision Scientific, Seoul, Korea)에서 24시간 동안 배양하여 준비하였다. 부추 발효물은 부추 추출물에 유산 균 전배양액을 $1 \%(\mathrm{v} / \mathrm{v})$ 가 되도록 접종하고 48 시간 동안 배양하여 제조하였다. 실험동물에 투여를 위한 부추 추출 물은 앞서 준비한 부추 추출물을 감압 농축기 $(\mathrm{N}-1000$, EYELA, Tokyo, Japan)로 농축한 다음 동결건조기(Freezone Plus 12, Labconcon Co., Kansas City, MO, USA)를 이용하여 동결건조 하여 사용하였으며, 부추 발효물은 L. casei와 $L$. plantarum 균주를 사용하여 상기와 동일하게 배양한 배양 액을 동결 건조하여 준비하였다.

\section{$\mathrm{pH}$ 및 산도 측정}

유산균으로 발효된 부추 발효물 및 부추 추출물의 $\mathrm{pH}$ 는 시료를 교반시키면서 $\mathrm{pH}$ meter(InLab413, Mettler Toledo, Greifensee, Switzerland)를 이용하여 측정하였다. 산도는 시 료를 $3,500 \mathrm{rpm}$ 으로 10 분간 원심분리하여 상등액을 회수한 후, 중화적정법(21)을 이용하여 측정하였다.

\section{생균수 측정}

생균수 측정은 $\mathrm{MRS}$ 평판배지에 멸균증류수를 이용하여 10 배로 단계별 희석한 부추 추출물 및 부추 발효물을 0.1 $\mathrm{mL}$ 씩 도말하여 $37^{\circ} \mathrm{C}$ 에서 24 시간 배양한 후, 배지에 형성된 colony의 수를 계수하여 시료 $1 \mathrm{~mL}$ 에 해당하는 colony forming units(CFU)로 나타내었다.

전자공여능 및 superoxide anion radical 소거능 측정

시료의 전자공여능(electron donating ability)을 통한 항산 화 활성 측정은 Yoon 등(22)의 방법을 변형하여 시행하였 다. 즉, 1,1-diphenyl-2-picryl-hydrazyl(DPPH, Wako, Tokyo, Japan) $6 \mathrm{mg}$ 을 ethanol $50 \mathrm{~mL}$ 에 녹인 후 동량의 증류수를 혼합하여 조제한 $\mathrm{DPPH}$ 시약 $5 \mathrm{~mL}$ 에 부추 추출물 또는 부추 발효물 $0.5 \mathrm{~mL}(1 \mathrm{mg} / \mathrm{mL})$ 를 넣어 잘 혼합한 후 암실에 서 15 분 간 방치한 다음, $517 \mathrm{~nm}$ 에서 흡광도를 측정하였다. 전자공여능은 시료 첨가 유무에 따른 흡광도 차이를 백분율 (\%)로 나타내었다.

\section{Electron donating ability $(\%)=(1-$ 시료 첨가군의 흡광도/시} 료 무 첨가군의 흡광도) $\times 100$

Superoxide anion radical(SOD) 소거능은 nitroblue tetrazolium(NBT) 환원법(23)에 의하여 측정하였다. 부추 
추출물 및 부추 발효물 $0.1 \mathrm{~mL}(1 \mathrm{mg} / \mathrm{mL})$ 에 $0.1 \mathrm{M}$ potassium phosphate buffer $0.6 \mathrm{~mL}$ 를 넣어 잘 혼합한 후 여기에 0.4 $\mathrm{mM}$ xanthine 용액과 $0.24 \mathrm{mM} \mathrm{NBT}$ 용액을 $1: 1$ 로 혼합한 용액 $1 \mathrm{~mL}$ 를 첨가하고 $0.049 \mathrm{U} / \mathrm{mL}$ 의 xanthine oxidase 1 $\mathrm{mL}$ 를 가하여 혼합하였다. 이를 $37^{\circ} \mathrm{C}$ 에서 20 분 반응시킨 후, $1 \mathrm{~N} \mathrm{HCl} 1 \mathrm{~mL}$ 를 첨가하여 반응을 정지시킨 다음 560 $\mathrm{nm}$ 에서 흡광도 측정하였다. superoxide anion radical 소거능 은 시료 첨가 유무에 따른 흡광도 차이를 백분율(\%)로 나타 내었다.

Superoxide anion radical 소거능 $(\%)=(1-$ 시료첨가군의 흡 광도시료 무 첨가군의 흡광도) $\times 100$

\section{실험동물}

본 실험에서는 제 2 형 당뇨의 대표적인 동물모델인 5 주령 수컷의 C57BLKS/J Iar-+Lepr ${ }^{\mathrm{db}} /+\operatorname{Lepr}^{\mathrm{db}}(d b / d b)$ mice와 비당 뇨 C57BLKS/J Iar-m+/m+ mice를 (주)중앙실험동물(Seoul, Korea)에서 공급받아 사용하였다. 실험동물사에서 1 주일 간 순화 및 적응시킨 후 체중과 혈당을 측정하여 병리적인 특이 소견이 없고 실험 사용에 적합한 mice를 선별하여 사용하였다. 실험기간 중 사료와 물은 자유로이 섭취시켰 으며 사육실의 온도는 $22 \pm 2^{\circ} \mathrm{C}$, 습도는 $55 \pm 15 \%$ 그리고 명암 은 12시간 주기를 유지하였다. 실험군 및 투여 용량은 streptozotocin 유발 당뇨 흰쥐에서 Ichnocarpurs frutescens 추출물의 항고혈당 유효성 평가, 톳 추출물의 항산화 효과 및 $d b / d b$ 마우스를 사용한 밀순 물 추출물의 항당뇨 평가와 같은 선행연구를 참고하여 설정하였다 $(11,24,25)$. 즉, 실험 군은 정상군(normal), 당뇨군(diabetes mellitus, DM), 200 $\mathrm{mg} / \mathrm{kg}$ 부추 추출물을 투여한 Allium tuberosum Rottler extracts(ATE)200군, $400 \mathrm{mg} / \mathrm{kg}$ 부추 추출물을 투여한 ATE400군, $200 \mathrm{mg} / \mathrm{kg}$ 부추 발효물을 투여한 FATE200군 그리고 $400 \mathrm{mg} / \mathrm{kg}$ 부추 발효물을 투여한 FATE 400 군으로 나누었으며 각 군에 5 마리씩 배정하여 실험하였다. 이 동물 실험은 (재)대구테크노파크 바이오헬스융합센터 동물실험 윤리위원회의 승인(승인번호: BHCC-IACUC-2013-12)을 받아 수행되었다.

\section{실험시료의 처치}

순화 및 적응기간이 지난 후, normal군과 $\mathrm{DM}$ 군에는 생리 식염수를 경구투여하고 ATE200군과 ATE400군에는 부추 추출물을 각각 $200 \mathrm{mg} / \mathrm{kg}, 400 \mathrm{mg} / \mathrm{kg}$ 농도로 경구투여 하였 으며, FATE200군과 FATE400군에는 부추 발효물을 각각 $200 \mathrm{mg} / \mathrm{kg}, 400 \mathrm{mg} / \mathrm{kg}$ 농도로 경구투여 하였다. 실험시료는 생리식염수 $200 \mu \mathrm{L}$ 에 각 농도별로 희석하여 7주 동안 매일 1 회 동일한 시간에 투여하였다.

체중 및 식이섭취량 측정

실험기간 동안 각 실험군 mice의 체중은 전자저울을 이
용하여 주 1 회 측정하였으며, 실험개시일의 체중을 7 주 후 의 최종 체중에 감하여 체중변화를 산출하였다. 식이섭취 량은 총 7 주의 실험기간동안 1 주일 단위로 제공된 사료량 에서 잔량을 감하여 주 평균 섭취량을 계산하였다.

\section{혈당변화 측정}

각 실험군 mice의 혈당 변화를 분석하기 위해 매주 1 회 12 시간 절식시킨 후 꼬리정맥에서 혈액을 채취하여 혈당측 정기(Accu-Check Active, Roche Diagnostics, Basel, Switzerland)로 혈당을 측정하였다. 혈당 증가량은 실험개 시일의 혈당을 7 주 후의 최종 혈당에 감하여 혈당변화를 산출하였다.

\section{경구 당 부하 검사}

각 실험군 mice의 포도당 내성능을 평가하기 위하여 실 험 종료일에 경구 당 부하 검사를 실시하였다. 12 시간 절식 시킨 mice에 glucose를 $2 \mathrm{~g} / \mathrm{kg}$ body weight의 용량으로 경구 투여하고 혈 액을 $0,30,60,120$ 분 간격으로 꼬리정맥에서 채취하여 혈당 농도를 측정하였다. 당 부하 검사에 따른 혈당곡선 면적(area under the curve, AUC)은 아래의 공식을 이용하여 산출하였다(26).

$$
\begin{gathered}
\mathrm{AUC}_{\mathrm{OGTT}}(\mathrm{mg} \times \mathrm{min} / \mathrm{dL})=\{(\mathrm{M} 2+\mathrm{M} 1) / 2\}+\{(\mathrm{M} 3+\mathrm{M} 2) / 2\}+\{( \\
\mathrm{M} 4+\mathrm{M} 3) / 2\}
\end{gathered}
$$

( $\mathrm{M} 1=0$ 분, $\mathrm{M} 2=30$ 분, $\mathrm{M} 3=60$ 분, $\mathrm{M} 4=120$ 분 경과 후의 혈당)

\section{혈청 내 Insulin 및 GLP-1 농도 측정}

실험 종료일에 각 실험군 mice의 심장으로부터 채취한 혈액을 $3,000 \mathrm{rpm}$ 에서 15 분간 원심분리한 후 혈청을 획득하 고 Mouse Insulin ELISA Kit(Shibayagi, Gunma, Japan)를 이용하여 혈청 내 insulin 농도를 측정하였다. Anti-insulin coated 96 well plate에 혈청 $10 \mu \mathrm{L}$ 를 넣고 20 25 ${ }^{\circ} \mathrm{C}$ 에서 2시 간 동안 방치한 후 washing buffer로 4회 세척하였다. 다시 $\mathrm{HRP}$ conjugated streptavidin $100 \mu \mathrm{L}$ 를 넣고 $20 \sim 25^{\circ} \mathrm{C}$ 에서 30 분간 배양한 후에 다시 4 회 세척하였다. 이어서 substrate chromogen reagent $100 \mu \mathrm{L}$ 를 넣고 $20 \sim 25^{\circ} \mathrm{C}$ 에서 20 분간 배양 한 후, $50 \mu \mathrm{L}$ 의 reaction stopper를 첨가하고 multi microplate reader(infinite M200PRO, Tecan, Männedorf, Switzerland)를 이용하여 $450 \mathrm{~nm}$ (reference wavelength, $620 \mathrm{~nm}$ )에서 흡광 도를 측정하였다.

혈청 내 glucagon-like peptide(GLP)-1 농도는 GLP-1 ELISA Kit(Shibayagi)를 이용하여 측정하였다. anti-GLP-1 coated 96 well plate에 혈청 $10 \mu \mathrm{L}$ 와 buffer solution $40 \mu \mathrm{L}$ 를 혼합하여 각각의 well에 $50 \mu \mathrm{L}$ 씩 분주하고 $20 \sim 25^{\circ} \mathrm{C}$ 에서 2시간 동안 방치한 후 washing buffer로 3회 세척하였다. 다시 biotin-labeled anti-GLP-1 solution $50 \mu \mathrm{L}$ 를 넣고 20 2 $5^{\circ} \mathrm{C}$ 에서 2 시간 동안 배양한 후에 다시 3 회 세척하였다. 이어 서 HRP-conjugated avidin solution $50 \mu \mathrm{L}$ 를 넣고 $20 \sim 25^{\circ} \mathrm{C}$ 에 
서 30 분간 배양한 후 다시 세척하였다. 마지막으로 chromogenic substrate reagent $50 \mu \mathrm{L}$ 를 넣고 $20 \sim 25^{\circ} \mathrm{C}$ 에서 30 분간 배양한 후, $50 \mu \mathrm{L}$ 의 reaction stopper를 첨가하고 multi microplate reader를 이용하여 $450 \mathrm{~nm}$ (reference wavelength, $620 \mathrm{~nm}$ )에서 흡광도를 측정하였다.

\section{통계분석}

실험 결과의 분석은 statistical package for social science(SPSS, 12.0, SPSS Inc, Chicago, IL, USA)program을 이용하여 기술적인 통계치를 산출하였다. 결과는 각 실험 군별 평균 \pm 표준편차로 표시하였으며, 평균 간의 유의성은 one way ANOVA 검증을 통한 Duncan's multiple range test 로 $\mathrm{p}<0.05$ 수준에서 검증하였다.

\section{결과 및 고찰}

\section{부추 추출물의 발효를 위한 균주 선발}

부추 추출물 발효를 위한 적합한 유산균의 선발을 위해 부추 추출물에 L. acidophilus, L. plantarum, L casei 균주를 각각 접종하고 48 시간 후 생균수, $\mathrm{pH}$, 산도를 측정하였다 (Table 1). 부추 추출물과 비교 시 부추 발효물에서는 유산균 의 발효 경향(27)과 동일하게 $\mathrm{pH}$ 는 감소하였으며, 산도는 증가되었다. 이러한 $\mathrm{pH}$ 감소 및 산도의 증가는 $L$. acidophilus를 접종한 군에 비해 L. plantarum과 L. casei를 접종한 군에서 더 크게 나타났다. 부추 발효물에서의 균주 생육에서도 L. acidophilus $\left(3.95 \times 10^{6} \mathrm{CFU} / \mathrm{mL}\right)$ 에 비해 $L$. plantarum $\left(2.60 \times 10^{7} \mathrm{CFU} / \mathrm{mL}\right)$ 과 L. casei $\left(4.20 \times 10^{7} \mathrm{CFU} / \mathrm{mL}\right)$ 가 더 우수하였다. 발효가 진행되면 젖산균에 의해 생성된 유기산에 의해 발효물의 산도는 증가된다(28). 따라서 $L$. plantarum과 $L$ casei 부추 발효물에 있어 $\mathrm{pH}$ 와 산도 변화는 부추 추출물에서 L. acidophilus보다 L. plantarum과 $L$ casei 의 균주 생육이 더 높음에 따라 발효가 더욱 활성화 되어 나타난 결과로 생각되어진다.
당뇨병에서는 산화적 스트레스 감소도 중요함으로 부추 발효를 위한 유산균 선발을 위해 $1 \mathrm{mg} / \mathrm{mL}$ 농도의 부추 추출물 및 부추 발효물을 이용한 전자공여능과 superoxide anion radical 소거능을 측정하여 항산화 활성을 조사하였다 (Table 1). 부추 추출물의 전자공여능은 Ahn 등(29)의 선행 연구 결과와 유사한 $24.74 \pm 1.42 \%$ 로 나타났다. 부추 발효물 경우, L. acidophilus를 접종한 부추 발효물에서는 $15.32 \pm$ $2.12 \%$ 로 부추 추출물보다 전자공여능이 저하되었지만 $L$. plantarum(64.71 $\pm 0.64 \%)$ 과 L. casei $(44.72 \pm 0.67 \%)$ 를 접종 한 경우에는 약 2 배 이상 증가되는 것을 확인할 수 있었다. Jeong 등(30)의 연구에서 항산화활성을 가지는 오미자 추출 이 산화적 손상된 $\beta$-cell에서 인슐린 분비 개선시킬 수 있다 고 보고 하였는데 이때, 오미자 추출물의 전자공여능은 $L$. plantarum 접종한 부추 발효물과 유사한 수준 이였다. 따라 서 L. plantarum를 접종한 부추 발효물의 전자공여능은 항 당뇨에 유의적 효과를 일으킬 수 있을 것으로 생각되어진 다. 그러나 superoxide anion radical 소거능에서는 $L$ casei를 접종한 부추 발효물에서만 $63.07 \pm 12.71 \%$ 로 부추 추출물 $(51.16 \pm 8.32 \%)$ 보다 높게 나타났으며, L acidophilus를 접종 한 부추 발효물 $(4.1 \pm 0.96 \%)$ 에서는 오히려 크게 감소되었 다. 전자공여능과 superoxide anion radical 소거능의 측정은 항산화 측정에 쓰이는 대표적인 방법으로 잘 알려져 있다. 산화적 스트레스가 주어진 췌장베타세포에서는 세포의 모 양이 변화하고 세포 사멸이 일어나 결과적으로 포도당 자극 에 대한 인슐린 분비능이 감소한다(31). Kim 등(32)은 인슐 린 분비를 저하된 췌장 소도에 항산화제인 vitamin $\mathrm{E}, \mathrm{a}$ -lipoic acid의 처리 시 산화적 스트레스에 의한 췌장 손상을 방지하여 인슐린 분비 장애를 방지 할 수 있다고 보고하였 다. 따라서 상기 연구 결과는 부추 추출물에 L. plantarum 및 L casei를 이용한 발효 시 활성산소 제거능을 증가시킴 으로 항산화 활성에 더 높은 효과를 일으킬 수 있어 당뇨병 의 항산화체계에 긍정적 영향을 줄 것을 제시한다.

$\mathrm{pH}$ 의 저하는 부패균에 의한 변성방지 역할을 하고 정상 적인 발효가 일어나게 한다(33). 이를 감안해 볼 때, $L$.

Table 1. Effects on cell growth, $\mathrm{pH}$, acidity and anti-oxidative activity of Allium tuberosum Rottler extracts fermented with lactic acid bacteria

\begin{tabular}{|c|c|c|c|c|c|}
\hline Group & Viable cell $(\mathrm{CFU} / \mathrm{mL})$ & $\mathrm{pH}$ & Titratable acidity & DPPH $(\%)$ & $\begin{array}{c}\text { Superoxide anion } \\
\text { radical scavenging (\%) }\end{array}$ \\
\hline $\mathrm{N} / \mathrm{F}^{1)}$ & - & $6.26 \pm 0.01^{5}$ & $0.25 \pm 0.03$ & $24.74 \pm 1.42$ & $51.16 \pm 8.32$ \\
\hline L. acidophilus') & $3.95 \times 10^{6}$ & $4.91 \pm 0.01$ & $0.66 \pm 0.01$ & $15.32 \pm 2.12$ & $4.10 \pm 0.96$ \\
\hline L. plantarum $\left.{ }^{3}\right)$ & $2.60 \times 10^{7}$ & $3.67 \pm 0.01$ & $1.88 \pm 0.03$ & $64.71 \pm 0.64$ & $33.71 \pm 6.43$ \\
\hline L. caseI $\left.^{4}\right)$ & $4.20 \times 10^{7}$ & $3.66 \pm 0.01$ & $1.71 \pm 0.06$ & $44.72 \pm 0.67$ & $63.07 \pm 12.71$ \\
\hline
\end{tabular}

${ }^{1)} \mathrm{N} / \mathrm{F}:$ Allium tuberosum Rottler extracts (ATE).

${ }^{2)} L$ acidophilus : ATE incubated for 2 day at $37^{\circ} \mathrm{C}$ after inoculating $L$ acidophilus.

${ }^{3)} L$ plantarum : ATE incubated for 2 day at $37^{\circ} \mathrm{C}$ after inoculating $L$ plantarum.

${ }^{4} L$ casei : ATE incubated for 2 day at $37^{\circ} \mathrm{C}$ after inoculating $L$. casei.

${ }^{5)}$ Values are mean \pm SD of three replications. 
plantarum과 L. casei는 부추 추출물에서 균주 생육이 우수 하며, $\mathrm{pH}$ 저하와 산도 증가를 통해 이상발효를 방지할 수 있음으로 부추 발효 시에 항산화성을 증가 시킬 수 있는 $L$. plantarum과 $L$. casei를 부추 추출물의 발효를 위한 후보 균주로 선발하였다.

부추 추출물의 L. plantarum과 L. casei를 이용한 혼합발효

부추 발효물 제조에 이용 될 균주를 최종 선발하기 위해 L. plantarum과 L. casei 균주를 각각 접종한 부추 발효물 및 두 균주를 동시에 접종한 부추 발효물의 항산화성에 대한 영향을 조사하였다(Table 2). 부추 추출물에 $L$. plantarum과 L casei를 접종하고 48시간 후에 $\mathrm{pH}$ 를 측정한 결과, 부추 추출물 $(6.29 \pm 0.00)$ 과 비교 시 L. plantarum을 접 종한 부추 발효물 $(3.61 \pm 0.01), \mathrm{L}$. casei를 접종한 부추 발효 물(3.61 \pm 0.00$), L$ plantrum과 $L$. casei를 동시에 접종한 부추 발효물(3.59 \pm 0.01$)$ 은 모두 $\mathrm{pH}$ 가 감소하였으며, 부추발효물 간의 $\mathrm{pH}$ 는 서로 유사하였다. 산도 측정결과도 부추 발효 시에 증가되었으며, $\mathrm{pH}$ 와 동일하게 부추 발효물 사이에는 큰 차이가 나타나지 않았다. $\mathrm{pH}$ 와 산도의 측정결과로 볼 때, $L$ plantarum과 $L$ casei를 혼합하여 부추 발효 시 특이적 변화는 관찰 할 수 없었다.

L. plantarum과 $L$ casei 균주 모두를 접종하여 부추 추출 물을 발효 시, 항산화 활성에 대해 시너지적 효과를 가지는 지 확인하였다. 우선, 부추 추출물 및 부추 발효물 $(1 \mathrm{mg} / \mathrm{mL})$ 을 이용하여 전자공여능을 조사한 결과, 부추 추출물에서 는 $24.82 \pm 0.31 \%, L$. plantarum과 L. casei를 둘 다 접종하여 발효시킨 부추 추출물에서는 $46.70 \pm 0.61 \%$ 로 발효에 의해 전자공여능은 증가 하였으나 L. plantarum 단일 균주로 발 효한 부추 발효물에서의 전자공여능보다 낮았다. 전자공여 능 측정과 동일한 농도의 부추 추출물 및 부추 발효물을 이용한 superoxide anion radical 소거능 측정 결과에서도 L. plantarum과 L. casei를 둘 다 접종하여 발효시킨 부추 발효물 $(60.59 \pm 1.09 \%)$ 과 비교해 볼 때, $L$ casei 단일 균주로 발효한 부추 발효물 $65.12 \pm 1.02 \%)$ 에서 조금 더 높았다. 전 자 공여능에 있어 단일 균주를 이용한 부추 발효물과 두
가지 유산균을 이용한 부추 혼합 발효물을 비교하여 보았을 때, 부추 혼합 발효물에서 전자공여능이 증가 되지는 않았 다. 그러나 선행 연구들에 따르면 발효물 제조 시 두가지 균주를 혼합하여 사용하면 생리기능성과 항산화활성이 증 가된다고 보고된 바 있으며 $(34,35)$, 본 연구에서 $L . c a s e i$ 와 L. plantarum을 접종하여 부추 발효 시 L. plantarum 부추 발효물에서 나타나는 superoxide anion radical 감소를 다소 보완 할 수 있음으로 $L$ plantarum과 L. caser를 부추 발효물 제조의 최종 균주로 선발하고 두 균주를 부추 추출물에 모두 접종하여 발효 시킨 후 동물실험에 시료로 사용하였 다. 이 때, 부추 추출물과 부추 발효물의 수율은 각각 $3.48 \%$, $3.40 \%$ 였으며, 총 폴리페놀 함량은 부추 추출물이 102.79 $\mathrm{mg} / 100 \mathrm{~g}$, 부추 발효물이 $102.91 \mathrm{mg} / 100 \mathrm{~g}$ 으로 두 시료 간 수율과 총 폴리페놀 함량은 큰 차이를 나타내지 않았다.

\section{체중 증가량과 식이섭취량}

$d b / d b$ mice에 농도를 달리한 부추 추출물과 부추 발효물 을 7주간 투여하고 각 실험군별 체중 증가량을 측정한 결과, normal군은 $4.72 \pm 0.7 \mathrm{~g}, \mathrm{DM}$ 군은 $10.67 \pm 1.3 \mathrm{~g}$ 그리고 부추 추출물 및 부추 발효물을 투여한 ATE200, ATE400, FATE200, FATE400군은 각각 $8.68 \pm 1.5 \mathrm{~g}, 7.99 \pm 2.1 \mathrm{~g}$, $5.44 \pm 0.7 \mathrm{~g}, 6.22 \pm 1.9 \mathrm{~g}$ 으로 나타났다(Fig. 1A). 모든 실험군 에서 체중은 실험기간 동안 증가하였지만 $\mathrm{DM}$ 군에 비해 부추 추출물 및 부추 발효물을 투여한 실험군에서 체중증가 량이 낮은 경향을 나타내었다. 특히 저농도의 부추 발효물 을 투여한 군(FATE200)에서는 체중증가의 억제효과가 유 의적으로 나타났다 $(\mathrm{p}<0.05)$. 체중변화와 식이섭취량의 관 계를 확인하기 위해, 총 실험기간 동안 일정시간에 사료 감소량을 측정하여 1 주일 동안의 평균 식이섭취량을 비교 하였다. 각각의 식이섭취량은 normal군 $101.23 \pm 27.87 \mathrm{~g}$, $\mathrm{DM}$ 군 $178.33 \pm 12.26 \mathrm{~g}, \mathrm{ATE} 200$ 군 $169.86 \pm 27.43 \mathrm{~g}, \mathrm{ATE} 400$ 군 $160.43 \pm 14.24 \mathrm{~g}$, FATE200군 $157.53 \pm 35.97 \mathrm{~g}$, FATE400 군 $163.98 \pm 2.47 \mathrm{~g}$ 으로 $\mathrm{DM}$ 군과 부추 추출물 및 부추 발효물 을 투여한 실험군 간의 식이섭취량은 유의적 차이가 없었다 (Fig. 1B). $d b / d b$ mice는 leptin 수용체 유전자의 변이에 따라

Table 2. Effects of $\mathrm{pH}$, acidity and anti-oxidative activity of Allium tuberosum Rottler extracts fermented with $L$. plantarum and $L$. casei

\begin{tabular}{|c|c|c|c|c|}
\hline Group & $\mathrm{pH}$ & Titratable acidity & DPPH (\%) & $\begin{array}{c}\text { Superoxide anion } \\
\text { radical scavenging (\%) }\end{array}$ \\
\hline $\mathrm{N} / \mathrm{F}^{1)}$ & $6.29 \pm 0.00^{5}$ & $0.25 \pm 0.01$ & $24.82 \pm 0.31$ & $54.82 \pm 0.31$ \\
\hline L. plantarun ${ }^{2}$ & $3.61 \pm 0.01$ & $1.61 \pm 0.07$ & $69.81 \pm 0.53$ & $33.89 \pm 0.58$ \\
\hline L. caset ${ }^{3)}$ & $3.61 \pm 0.00$ & $1.51 \pm 0.05$ & $45.12 \pm 1.02$ & $65.12 \pm 1.02$ \\
\hline$L$ plantarum $\left.{ }^{4}\right)+L$ casei & $3.59 \pm 0.01$ & $1.66 \pm 0.05$ & $46.70 \pm 0.61$ & $60.59 \pm 1.09$ \\
\hline
\end{tabular}

${ }^{1)} \mathrm{N} / \mathrm{F}:$ Allium tuberosum Rottler extracts (ATE).

${ }^{2)} L$ plantarum : ATE incubated for 2 day at $37^{\circ} \mathrm{C}$ after inoculating $L$ plantarum.

${ }^{3)} L$ casei : ATE incubated for 2 day at $37^{\circ} \mathrm{C}$ after inoculating $L$. casei.

${ }^{4)} L$ casei : ATE incubated for 2 day at $37^{\circ} \mathrm{C}$ after inoculating both $L$. plantarum and $L$. casei.

${ }^{5)}$ Values are mean \pm SD of three replications. 

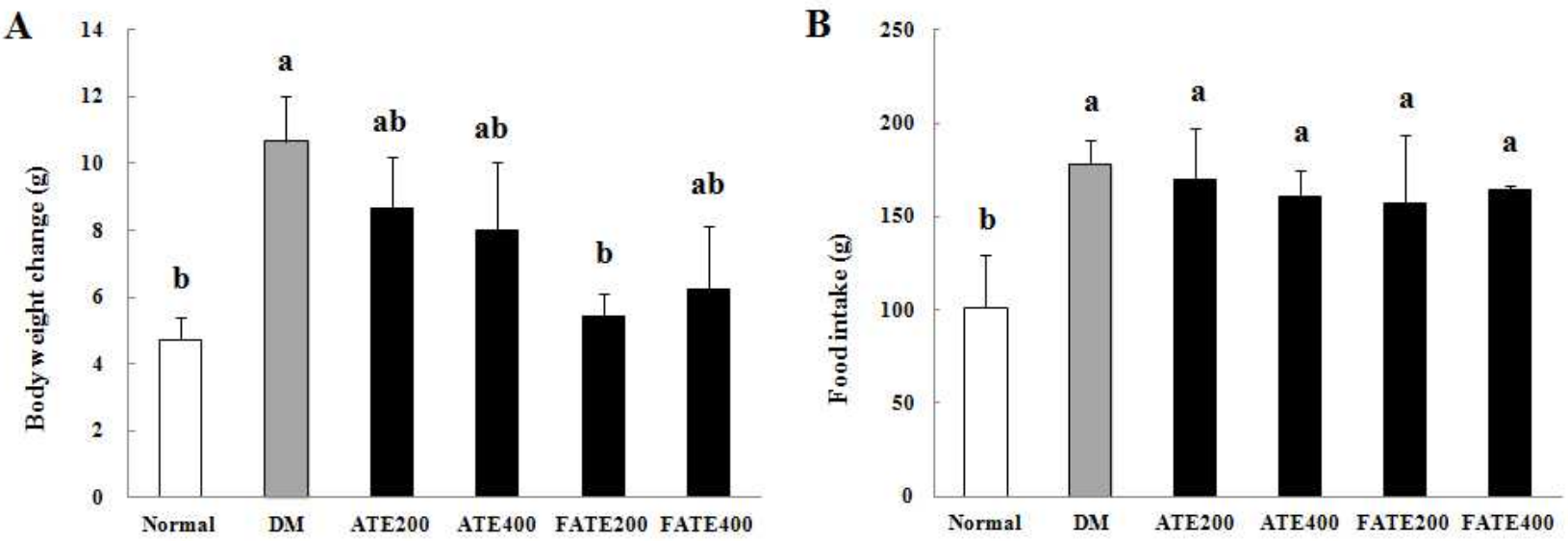

Fig. 1. Changes in the body weights (A) and food intakes (B) of the experimental groups.

The different superscripts on the bars indicate significant differences at $\mathrm{p}<0.05$. Normal, non-diabetic mice; DM, diabetic mice; ATE 200 , the diabetic mice treatment of 200 $\mathrm{mg} / \mathrm{kg} /$ day Allium tuberosum Rottler extracts; ATE 400, the diabetic mice treatment of $400 \mathrm{mg} / \mathrm{kg} /$ day ATE; FATE 200, the diabetic mice treatment of $200 \mathrm{mg} / \mathrm{kg} /$ day Allium tuberosum Rottler extracts fermented (FATE) with $L$. plantarum and $L$ casei, FATE 400, the diabetic mice treatment of $400 \mathrm{mg} / \mathrm{kg} / \mathrm{day}$ FATE. The data represent mean \pm SD ( $\mathrm{n}=5$ per group).

leptin에 대한 저항성이 발생되어 식욕이 조절되지 않고 결 과적으로 비만이 나타나는 당뇨모델이다(36). 따라서 DM 군과 실험군에서의 체중 증가는 제2형 당뇨병 유발로 인해 식이섭취량이 정상군에 비해 증가되어 나타난 결과이다. 그러나 실험군 간(DM군, ATE200군, ATE400군, FATE200 군, FATE400군)의 식이섭취량 차이가 없는 것을 감안 해 볼 때, $d b / d b$ mice에서 부추 추출물 및 부추 발효물은 식욕조 절과 관계없이 체중증가를 억제시킬 수 있는 것으로 판단되 며, 본 실험 결과를 통해 부추 추출물 보다 부추 발효물이 비만을 동반하는 제2형 당뇨의 체중증가를 억제시키는데 더 효과적인 것을 확인하였다.

\section{혈당변화량 및 혈당증가량}

총 7 주간의 실험기간 동안 혈당은 1 주 간격으로 일정한 시간에 측정하였으며, 각 실험군별 혈당량의 변화는 Table 3 에 나타내었다. 실험 개시일의 혈당을 7주 후의 최종 혈당 에 감하여 혈당증가량을 측정한 결과, normal군은 $24.8 \pm 8.9$ $\mathrm{mg} / \mathrm{dL}, \mathrm{DM}$ 군은 $149.6 \pm 11.9 \mathrm{mg} / \mathrm{dL}$ 그리고 부추 추출물 및 부추 발효물을 투여한 ATE200, ATE400, FATE200, FATE400군은 각각 $105.8 \pm 8.8 \mathrm{mg} / \mathrm{dL}, 57.2 \pm 28.8 \mathrm{mg} / \mathrm{dL}$, $136.2 \pm 20.5 \mathrm{mg} / \mathrm{dL}, 96.8 \pm 30.7 \mathrm{mg} / \mathrm{dL}$ 로 나타났다(Fig. 2). Normal군에 비해 DM군 mice의 혈당이 크게 증가되었으며, 이러한 혈당증가는 부추 추출물 및 부추 발효물의 투여로

Table 3. Blood glucose levels of non-diabetic and $d b / d b$ mice to whom ATE and FATE were administered

\begin{tabular}{|c|c|c|c|c|c|c|}
\hline Week & Normal $^{1)}$ & $\mathrm{DM}^{2)}$ & ATE200 & ATE400 & FATE200") & FATE400 \\
\hline 0 & $103.6 \pm 3.5^{\mathrm{a} 7)}$ & $430.4 \pm 11.4^{b}$ & $465.6 \pm 16.1^{b}$ & $468.2 \pm 23.3^{b}$ & $437.4 \pm 20.2^{b}$ & $452.0 \pm 21.7^{b}$ \\
\hline 1 & $108.6 \pm 4.0^{\mathrm{a}}$ & $515.4 \pm 15.3^{b}$ & $498.4 \pm 16.5^{b}$ & $496.6 \pm 29.4^{b}$ & $499.0 \pm 29.4^{\mathrm{b}}$ & $444.4 \pm 14.5^{b}$ \\
\hline 2 & $101.8 \pm 5.2^{\mathrm{a}}$ & $524.6 \pm 13.5^{b}$ & $530.0 \pm 16.2^{b}$ & $512.0 \pm 28.8^{\mathrm{b}}$ & $536.2 \pm 15.6^{\mathrm{b}}$ & $520.6 \pm 10.6^{b}$ \\
\hline 3 & $115.0 \pm 4.7^{\mathrm{a}}$ & $536.2 \pm 11.9^{b}$ & $543.6 \pm 12.1^{b}$ & $540.0 \pm 19.6^{\mathrm{b}}$ & $545.0 \pm 14.9^{\mathrm{b}}$ & $545.0 \pm 13.0^{b}$ \\
\hline 4 & $112.6 \pm 4.1^{\mathrm{a}}$ & $561.4 \pm 16.2^{b}$ & $540.8 \pm 14.0^{b}$ & $533.8 \pm 16.8^{b}$ & $569.0 \pm 14.3^{\mathrm{b}}$ & $553.2 \pm 16.9^{b}$ \\
\hline 5 & $117.4 \pm 6.6^{\mathrm{a}}$ & $567.2 \pm 12.4^{\mathrm{bc}}$ & $558.0 \pm 12.5^{\mathrm{bc}}$ & $519.4 \pm 25.5^{\mathrm{b}}$ & $574.4 \pm 14.1^{\mathrm{c}}$ & $556.6 \pm 10.9^{b c}$ \\
\hline 6 & $119.8 \pm 3.9^{\mathrm{a}}$ & $580.2 \pm 5.0^{c}$ & $574.0 \pm 6.8^{\mathrm{c}}$ & $511.2 \pm 14.1^{\mathrm{b}}$ & $584.0 \pm 7.3^{\mathrm{c}}$ & $556.6 \pm 11.1^{\mathrm{c}}$ \\
\hline 7 & $128.4 \pm 5.7^{\mathrm{a}}$ & $580.0 \pm 6.0^{\mathrm{d}}$ & $571.4 \pm 8.1^{\mathrm{cd}}$ & $525.4 \pm 13.3^{b}$ & $573.6 \pm 6.1^{\mathrm{cd}}$ & $548.8 \pm 11.3^{\mathrm{b}}$ \\
\hline
\end{tabular}

\footnotetext{
${ }^{1)}$ Normal : non-diabetic mice.

${ }^{2)} \mathrm{DM}$ : diabetic mice.

${ }^{3)}$ ATE 200: Allium tuberosum rottler extracts (ATE) with concentration of $200 \mathrm{mg} / \mathrm{kg} /$ day orally administered to the diabetic mice

${ }^{4}$ ATE 400 : ATE with concentration of $400 \mathrm{mg} / \mathrm{kg} /$ day orally administered to the diabetic mice.

${ }^{5}$ FATE 200 : Allium tuberosum rottler extracts fermented (FATE) by $L$ plantarum and $L$ casei with concentration of $200 \mathrm{mg} / \mathrm{kg} / \mathrm{day}$ orally administered to the diabetic mice.

${ }^{6}$ FATE 400 : FATE of $400 \mathrm{mg} / \mathrm{kg} /$ day orally administered to the diabetic mice.

${ }^{7)}$ Values are mean \pm SD ( $\mathrm{n}=5$ per group).
} 
인해 억제되는 경향을 보였다. 특히 고농도의 부추 추출물 을 투여한 ATE400군에서 유의적인 혈당증가 억제효과를 확인할 수 있었으며, 그 다음으로는 고농도의 부추 발효물 을 투여한 FATE400군이었으나 유의성은 나타나지 않았다 ( $<<0.05)$. 이전 연구에 따르면 부추 및 마늘과 같은 Allium 속 식물의 장기간 섭취는 제 1 형 당뇨 모델에서 손상된 췌장 세포를 회복시키거나 호르몬 조절과 같은 작용을 하여 혈당 을 유의적으로 감소시킨다고 보고된 바 있다 $(37,38)$. 본 연 구 결과에서 부추 추출물은 제 2 형 당뇨 모델인 $d b / d b$ mice 에서도 혈당 상승의 억제효과가 유의적으로 나타나 부추의 지속적인 섭취는 제 1 형뿐만 아니라 제 2 형 당뇨에 있어 혈 당 조절에 긍정적 영향을 줄 수 있음을 확인 할 수 있었다. 또한 비록 통계적 유의성이 나타나지는 않았지만 고농도의 부추 발효물 역시 혈당 조절 효과의 경향을 나타내었다. $\mathrm{Kim}$ 등(39)당뇨질환 초기치료에서 경구혈당강하제로 많이 사용되는 합성 제제 'Metformin'을 $d b / d b$ mice에 투여 시 당뇨대조군 대비 혈당 증가량이 약 $77.9 \%$ 감소되었다고 보고하였다. 본 연구에서는 부추 추출물을 투여하였을 때 혈 당증가량이 대조군 대비 각각 $61.8 \%$ 감소하는 것으로 나타났다. 따라서 부추 추출물은 합성 제제인 'Metformin' 과 유사한 수준의 혈당강하효과가 있으며, 천연물 소재라 는 점에서 부작용이 적고 식품류를 비롯한 다양한 제품으로 의 활용 가치가 넓음으로 항당뇨 기능성 소재 시장에서 산업적 이용가치가 매우 높을 것으로 생각되어진다. 따라 서 부추 추출물 및 부추 발효물 투여에 대한 당 내성 실험과 혈청의 insulin 및 GLP-1 함량 측정을 추가로 시행하였다.

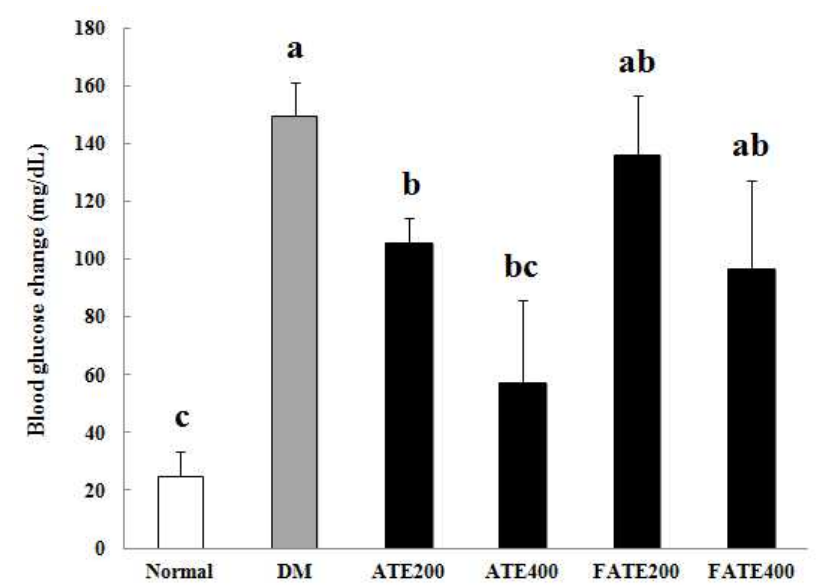

Fig. 2. Changes in the blood glucose levels of the non-diabetic and $d b / d b$ mice.

The different superscripts on the bars indicate significant differences at $p<0.05$. Normal, non-diabetic mice; DM, diabetic mice; ATE 200, the diabetic mice treatment of 200 $\mathrm{mg} / \mathrm{kg} /$ day Allium tuberosum Rottler extracts; ATE 400, the diabetic mice treatment of $400 \mathrm{mg} / \mathrm{kg} /$ day ATE; FATE 200, the diabetic mice treatment of $200 \mathrm{mg} / \mathrm{kg} /$ day Allium tuberosum Rottler extracts fermented (FATE) with $L$ plantarum and $L$ casei, FATE 400 , the diabetic mice treatment of $400 \mathrm{mg} / \mathrm{kg} /$ day FATE. The data represent mean $\pm \mathrm{SD}$ ( $\mathrm{n}=5$ per group).
경구 당 부하 검사와 혈당곡선 면적

각 실험군 mice에서의 부추 추출물 및 부추 발효물 투여 에 의한 포도당 내성 효과를 알아보기 위해 실험시료 투여 7주 경과 후, 경구 당 부하 검사를 실시하였다(Fig. 3A). 혈당곡선 면적을 계산하여 비교한 결과, normal군은

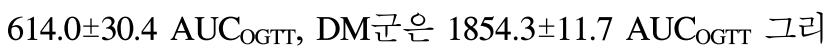
고 부추 추출물 및 부추 발효물을 투여한 ATE200, ATE400, FATE200, FATE400군은 각각 $1827.3 \pm 12.5 \mathrm{AUC}_{\mathrm{OGTT}}$, $1708.8 \pm 32.9$ AUC $_{\text {OGTT }}, 1826.9 \pm 14.3$ AUC $_{\text {OGTT }}, 1766.7 \pm 9.7$ $\mathrm{AUC}_{\mathrm{OGTT}}$ 로 나타났다(Fig. $\left.3 \mathrm{~B}\right)$. 이러한 결과는 고농도의 부 추 추출물 및 부추 발효물이 당뇨질환에 의해 손상된 내당 능을 유의적으로 개선시키는 것을 보여준다. 본 연구 결과 는 다양한 식물 추출물을 당뇨 모델에 투여하였을 때 통계 적으로 유의한 내당능 효과를 보고한 이전 연구들과 유사한 경향을 나타내었다 $(40,41)$. 제 2 형 당뇨병은 고혈당에 의한 합병증의 위험이 높은 것으로 알려져 있으며 당부하 검사에 서 고혈당 증상이 나타날 경우에는 동맥경화 및 심혈관 질환에 특히 위험하다고 알려져 있다 $(42,43)$. 이러한 질환 의 합병증 증가는 당뇨병에 의한 사망률을 증가시키는 원인 이 되기도 한다(44). 따라서 고농도의 부추 추출물 및 부추 발효물은 제 2 형 당뇨 모델인 $d b / d b$ mice의 내당능을 개선시 키고 당뇨 합병증을 효과적으로 예방할 수 있는 것으로 사료된다.

\section{혈청 내 Insulin 함량 변화}

부추 추출물 및 부추 발효물 투여에 의한 항당뇨 효과 유효성을 평가하기 위해 당뇨질환의 중요한 지표로 알려진 혈청 내 insulin 함량을 측정하였다. DM군의 혈청 내 insulin 농도는 $1331.90 \pm 302.16 \mathrm{pg} / \mathrm{mL}$ 이었고 부추 추출물 및 부추 발효물을 투여한 ATE200, ATE400, FATE200, FATE400군 은 각각 $793.55 \pm 163.31 \mathrm{pg} / \mathrm{mL}, 157.95 \pm 83.63 \mathrm{pg} / \mathrm{mL}$, $1364.65 \pm 403.53 \mathrm{pg} / \mathrm{mL}, 479.44 \pm 221.71 \mathrm{pg} / \mathrm{mL}$ 으로 나타났 다(Fig. 4A). Normal군(32.90 $8.24 \mathrm{pg} / \mathrm{mL}$ )과 비교하였을 때, $\mathrm{DM}$ 군에서 증가된 혈청 내 insulin 농도가 부추 추출물 및 부추 발효물 투여에 의해 감소되는 경향을 보였다. 특히 고농도의 부추 추출물을 투여한 ATE400군에서 유의적인 감소 효과가 나타났으며 고농도의 부추 발효물을 투여한 FATE400군에서도 크게 감소되는 경향을 나타내었다. Insulin은 췌장의 베타세포에서 분비되어지는 호르몬으로 써 혈당의 조절뿐만 아니라 지질과 단백질의 대사과정에서 도 중요한 역할을 한다. Insulin 비의존성 당뇨병인 대부분 의 제 2 형 당뇨병의 경우, 분비된 insulin이 조직의 insulin 저항성에 의해 체내 조직으로 이동하지 못하여 혈중 insulin 농도가 증가하게 된다(45). Insulin 저항성은 대사성 질환의 주된 병인으로 여겨지며 insulin 저항성에 의해 나타나는 hyperinsulinemia는 제 2 형 당뇨병뿐만 아니라 다양한 대사 이상의 표시자 역할을 한다 $(46,47)$. 따라서 본 연구결과는 

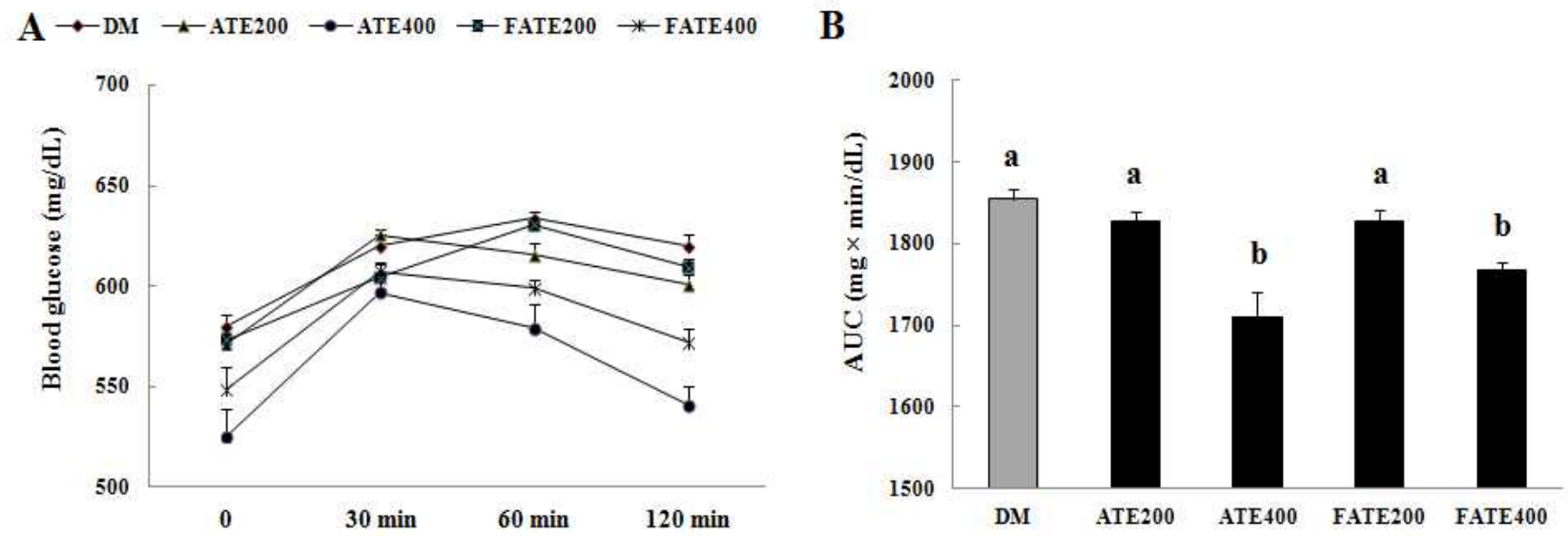

Fig. 3. Oral glucose tolerance test results of the non-diabetic and $d b / d b$ mice.

The different superscripts on the bars indicate significant differences at $\mathrm{p}<0.05$. Normal, non-diabetic mice; DM, diabetic mice; ATE 200, the diabetic mice treatment of 200 $\mathrm{mg} / \mathrm{kg} /$ day Allium tuberosum Rottler extracts; ATE 400, the diabetic mice treatment of $400 \mathrm{mg} / \mathrm{kg} / \mathrm{day}$ ATE; FATE 200, the diabetic mice treatment of $200 \mathrm{mg} / \mathrm{kg} / \mathrm{day}$ Allium tuberosum Rottler extracts fermented (FATE) with $L$. plantarum and $L$ caser, FATE 400, the diabetic mice treatment of $400 \mathrm{mg} / \mathrm{kg} /$ day FATE. The data represent mean \pm SD ( $\mathrm{n}=5$ per group).

$\mathbf{A}$

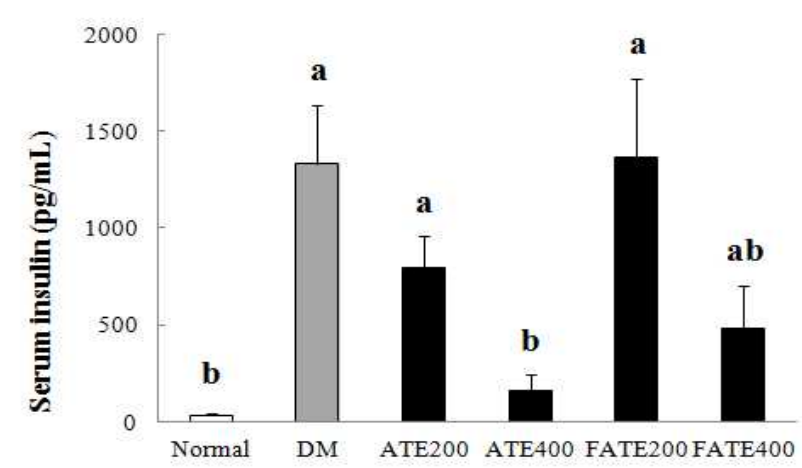

B

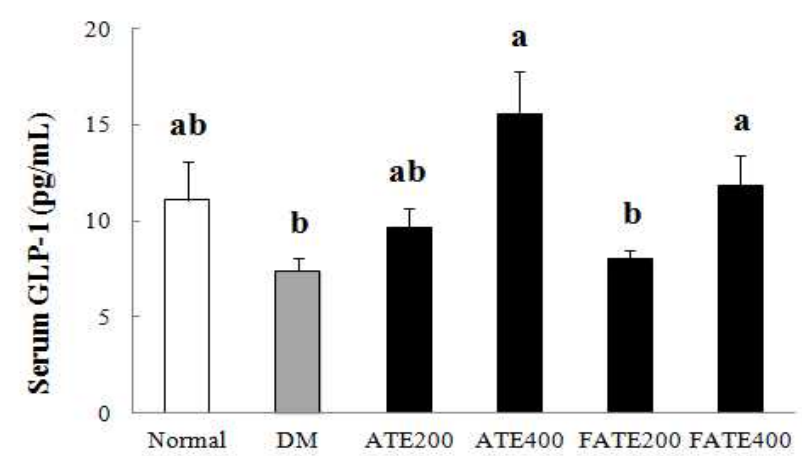

Fig. 4. Effects on the serum insulin (A) and GLP-1 levels (B) of the $d b / d b$ mice.

The different superscripts on the bars indicate significant differences at $\mathrm{p}<0.05$. Normal, non-diabetic mice; DM, diabetic mice; ATE 200, the diabetic mice treatment of 200 $\mathrm{mg} / \mathrm{kg} /$ day Allium tuberosum Rottler extracts; ATE 400, the diabetic mice treatment of $400 \mathrm{mg} / \mathrm{kg} /$ day ATE; FATE 200, the diabetic mice treatment of $200 \mathrm{mg} / \mathrm{kg} / \mathrm{day}$ Allium tuberosum Rottler extracts fermented (FATE) with $L$. plantarum and $L$ caser, FATE 400, the diabetic mice treatment of $400 \mathrm{mg} / \mathrm{kg} / \mathrm{day}$ FATE. The data represent mean \pm SD $(\mathrm{n}=5$ per group).

고농도의 부추 추출물 및 부추 발효물이 제 2 형 당뇨병에서 증가된 혈청 내 insulin 함량을 insulin 저항성 개선을 통해 조절할 수 있음을 보여주었다.

\section{혈청 내 GLP-1 함량 변화}

Insulin과 함께 당뇨질환의 지표 중 하나인 혈청 내 GLP-1 함량을 추가적으로 측정한 결과, DM군의 혈청 내 GLP-1 농도는 $7.40 \pm 0.65 \mathrm{pg} / \mathrm{mL}$ 이었고 부추 추출물 및 부추 발효물 을 투여한 ATE200, ATE400, FATE200, FATE400군은 각각 $9.65 \pm 0.98 \mathrm{pg} / \mathrm{mL}, 15.52 \pm 2.26 \mathrm{pg} / \mathrm{mL}, 7.99 \pm 0.49 \mathrm{pg} / \mathrm{mL}$, $11.80 \pm 1.60 \mathrm{pg} / \mathrm{mL}$ 으로 나타났다(Fig. 4B). Normal군 $(11.10 \pm 1.98 \mathrm{pg} / \mathrm{mL})$ 과 비교하였을 때, $\mathrm{DM}$ 군에서 감소된
혈청 내 GLP-1 농도가 부추 추출물 및 부추 발효물 투여에 의해 증가되는 경향을 보였다. 특히 고농도의 부추 추출물 과 부추 발효물을 투여한 ATE400군, FATE400군에서 유의 적으로 증가되었다. GLP-1은 위장관의 L세포에서 분비되 는 호르몬으로써 glucose toxicity의 감소를 통해 공복 혈당 을 감소시키며 말초의 insulin 저항성을 개선시킨다 $(48,49)$. 제2형 당뇨병 환자에게 GLP-1을 투여하면 고혈당증이 감 소된다는 연구결과가 보고와 함께 GLP- 1 은 제 2 형 당뇨병 의 고혈당을 개선시키는 중요 지표로 알려져 있다(50). 제2 형 당뇨모델인 $d b / d b$ mice에서 고농도의 부추 추출물 및 부추 발효물 투여에 의한 혈청 내 GLP-1의 함량의 유의적 증가는 부추 추출물 및 부추 발효물이 insulin 저항성을 개선 
함으로써 혈당을 감소시킬 수 있음을 다시 한 번 제시해 주었다. 따라서 부추 추출물 및 부추 발효물은 GLP-1 분비 향상으로 인한 인슐린 저항성을 개선시키고 혈당강하를 유도하여 당뇨의 예방과 개선에 긍정적인 역할을 할 것으로 사료된다. 특히 앞선 체중측정 결과에서 유의적인 체중감 량 효과를 보인 부추 발효물은 비만과 함께 일어나는 제2형 당뇨형의 대사증후군의 예방 소재로써 산업적 활용이 기대 된다.

\section{요 약}

본 연구에서는 비 상품 부추의 산업적 활용의 활성화를 위해 제 2형 당뇨모델인 $\mathrm{db} / \mathrm{db}$ 마우스에서 부추 추출물과 부추 발효물에 대한 항당뇨 효과를 조사하였다. 부추 발효 물 제조를 위한 균주선발을 위해 L. acidophilus, $L$. plantarum, L. casei을 접종하여 배양시킨 부추 추출물(부추 발효물)에 대한 전자공여능을 측정한 결과, L acidophilus, L. plantarum 부추 발효물은 활성이 증가되었으나 $L$. plantarum 접종한 부추 발효물의 superoxide radical 소거능 은 부추 추출물의 0.6 배 수준으로 감소하였다. L plantarum 와 $L$ casei 균주를 접종한 부추 발효물의 superoxide radical 소거능은 부추 추출물과 유사한 수준을 나타내었다. 따라 서 L. plantarum과 $L$ caser를 이용하여 발효한 부추 발효물 과 부추 추출물을 제 2 형 당뇨질환 동물모델인 $d b / d b$ mice에 두 가지 농도구간으로(저농도 : $200 \mathrm{mg} / \mathrm{kg}$, 고농도 : 400 $\mathrm{mg} / \mathrm{kg}$ ) 경구 투여한 후, 항당뇨 효능을 평가하였다. 체중 및 식이섭취량을 측정한 결과, 저농도 부추 발효물을 투여 하였을 때, 식이섭취량의 변화 없이 체중증가량이 유의적 으로 감소되는 것을 확인할 수 있었다( $\mathrm{p}<0.05)$. 혈당증가량 과 혈청 내 insulin 함량은 고농도 부추 추출물을 투여하였을 때, 유의적으로 감소되었고, 부추 발효물을 투여한 군에서 도 감소되는 경향을 나타내었다( $\mathrm{p}<0.05)$. 경구 당 부하검사 결과에서도 고농도의 부추 추출물 및 부추 발효물을 투여한 군에서 포도당 내성 효과가 개선되는 것으로 나타났다. 당 뇨병에 의해 감소된 혈청 내 GLP-1 농도는 고농도 부추 추출물 및 고농도의 부추 발효물 투여로 인해 증가되었으며 이상의 결과들은 부추 추출물 및 부추 발효물이 GLP-1 분비 를 증가시켜 insulin 저항성을 개선시킬 수 있음을 나타낸다. 비록 본 연구결과에서 제 2 형 당뇨질환에 대한 항당뇨 효능 은 부추 추출물이 부추 발효물 보다 더 효과적인 것으로 나타났으나, 두가지 유산균으로 혼합발효한 부추 발효물은 부추 추출물과 유사한 수준의 항당뇨 효능을 보임과 동시에 제 2 형 당뇨병으로 인한 체중증가도 감소시킬 수 있어 비만 을 동반하는 제 2 형 당뇨병의 예방과 개선을 위한 기능성 소재로 활용될 수 있을 것이라 사료된다.

\section{References}

1. Flegal KM, Carroll MD, Kuczmarski RJ, Johnson CL (1998) Overweight and obesity in the United States: prevalence and trends, 1960-1994. J Obes Relat Metab Disord, 22, 39-47

2. Korean National Statistical Office (2010) Annual report on the cause of death statistics. 2010. Korean National Statistical Office, Seoul, Korea

3. Guthrie RA, Guthrie DW (2004) Pathophysiology of diabetes mellitus. Crit Care Nurs Q, 27, 113-125

4. Gonuth SM (1973) Plasma insulin and glucose profiles in normal, obese and diabetic persons. Am Intern Med, 79, 812-822

5. Semenkovich CF (2006) Insulin resistance and artherosclerosis. J Clin Invest, 116, 1813-1822

6. Wolff SP, Jiang ZY, Hunt JV (1998) Protein glycation and oxidative stress in diabetic mellitus. Free Radic Biol Med, 10, 339-352

7. Coppey LJ, Gellett JS, Davidson EP, Dunlap JA, Lund DD, Yorek MA (2001) Effect of antioxidant treatment of streptozotocin-induced diabetic rats on endoneurial blood flow, motor nerve conduction velocity, and vascular reactivity of epineurial arterioles of the sciatic nerve. Diabetes, 50, 1927-1937

8. Lee SZ, Park SH, Lee HS (2001) Change in in vivo lipid peroxidation and antioxidant defecse system in streptozotocin-induced diabetic rats : a time course study. Korean J Nutr, 34, 253-264

9. Bagg W, Plank LD, Gamble G, Drury PL, Sharpe N, Braatvedt GD (2001) The effects of intensive slycemic control on body composition in patients with type 2 diabetes. Diabetes Obes Metab, 3, 410-416

10. Srinivasan BT, Jarvis J, Khunti K, Davies MJ (2008) Recent advances in the management of type 2 diabetes mellitus : a review. Postgrad Med J, 84, 524-531

11. Lee SH, Lim SW, Lee YM, Hur JM, Lee HS, Kim DK (2010) Anti-diabetic effects of Triticum aestivum L. water extracts in $d b / d b$ mice as an animal model of diabetes mellitus type II. Korean J Pharmacogn, 41, 282-288

12. Min OJ Sharma BR, Park CM, Rhyu DY (2011) Effect of Myadis Stigma water extract on adipogenesis and blood glucose in 3T3-L1 adipocytes and $d b / d b$ mice. Korean J Pharmacogn, 42, 201-208

13. Lee JJ, Kim AR, Chang HC, Jung HO, Lee MY (2012) Effects of soybean and DJI Chungkukjang powder on blood glucose and serum lipid reduction in $d b / d b$ mice. 
J Korean Soc Food Sci Nutr, 41, 1086-1093

14. Yoo SO, Bae JH (1993) Investigation of Korean native chinese chives on flower bud differentiation. J Korean Soc Hort Sci, 34, 395-401

15. Kwak YJ, Jun HJ, Lee MJ, Kwon TW, Kim JS (1998) Modulation of anticarcinogenic enzyme and plasma testosterone level in male mouse fed leek-supplemented diet. J Korean Soc Food Sci Nutr, 27, 968-972

16. Hong JH, Lee MH, Kang MC, Hur SH (2000) Separation and identification of antimicrobial compounds from Korean leek (Allium tuberosum). J Fd Hyg Safety, 15, 235-240

17. Cha JY, Kim SK, Kim HJ, Song JY, Cho YS (2000) Chemical compositions and antioxidative activity of leek (Allium tuberusum) seeds. J Life Sci, 10, 273-278

18. Hubert J, Berger M, Nepveu F, Paul F, Dayd J (2008) Effects of fermentation on the phytochemical composition and antioxidant properties of soy germ. Food Chem, 109, 709-721

19. Han SK (2005) Quality improvement of effective microorganisms (EM) pork produced by using EM. J Korean Soc Food Sci Nutr, 34, 734-737

20. Park JH, Sung KS, Kim SS, shin GS, Han CK (2012) Effects of puffed and fermented red ginseng on blood glucose-related biomarkers in streptozotocin-induced diabetic rats. J Korean Soc Food Sci Nutr, 41, 630-637

21. Park SJ, Kim KD, Lee JR (2000) Influence of activation temperature of surface and adsorption properties of PAN-based activated carbon fibers/phenolic resin matrix composites. Polym Korea, 24, 97-104

22. Yoon SP, Lee MH, Kim HK, Lee GD (2006) Change in functional properties by extraction condition of roasted Pleurotus eryngii. J Korean Soc Food Sci Nutr, 26, 262-270

23. Parejo I, Viladomat F, Bastida J, Rosas-Romero A, Saavedra G, Muricia MA, Jimenez AM, Colina C (2003) Investigation of Bolivian plant extracts for their radical scavenging activity and antioxidant activity. Life Sci, 73, 1667-1681

24. Dash DK, Ghosh T, Yeligar VC, Murugesh K, Nayak SS, Maiti BC, Maity TK (2007) Effect of Ichnocarpus frutescens extract on antihyperglycemic, antihyperlipidemic and antioxidant status in streptozotocin-induced diabetic rats. Orient Pharm Exp Med, 7, 244-253

25. Ko MS, Shin KM, Lee MY (2002) Effects of Hijikia fusifome ethanol extract on antioxidative enzymes in ethanol-induced hepatotoxicity of rat liver. J Korean Soc
Food Sci Nutr, 31, 87-91

26. Pruessner JC, Kirschbaum C, Meinlschmid G, Hellharmmer DH (2003) Two formulas for computation of the area under the curve represent measures of total hormone concentration versus time-dependent change. Psychoneuroendocrinology, 28, 916-931

27. Shin DH (1989) A yogurt like product development from rice by lactic acid bacteria. Korean J Food Sci Technol, 21, 686-690

28. Lee JS, Lee TS, Noh BS, Park SO (1996) Quality characteristics of mash of Takju prepared by different raw materials. Korean J Food Sci Technol, 28, 330-336

29. Ahn MS, Kim HJ, Seo MS (2005) The antioxidative and antimicrobial activities of the three species of leeks (Allium tuberosun R.) ethanol extracts. Korean J Food Culture, 20, 186-193

30. Jeong YS, Hong JH, Jung HK (2011) Effect of the extracts from Schisandra chinensis fruit and Morus alba leaf on insulin secretion in glucose-induced HIT-T15 Cells. Korean J Food Preserv, 18, 1002-1008

31. Kwon MJ, Jung HS, Kim MK, Kang SH, Song GW, Song JK, Yoon TY, Jeon MK, Ha TH, Yoon CS, Lee WJ, Noh, JH, Kwon SK, Kim DJ, Koh KS, Rhee BD, Lim KH, Lee SH, Park JH (2007) Cytoprotective effect by antioxidant activity of quercetin in INS-1 cell line. J Korean Diabetes Assoc, 31, 383-390

32. Kim CH, Kim Ch, Park HK, Suh KI, Lee KU (2002) Effects of antioxidants on ethidium bromide-induced inhibition of insulin secretion in rat pancreatic islets. $\mathbf{J}$ Korean Diabetes Assoc, 26, 199-207

33. Seo MY, Lee JK, Ahn BH, Cha SK (2005) The changes of microflora during the fermentation of Takju and Yakju. Korean J Food Sci Technol, 37, 61-66

34. Jang IT, Kim YH, Na KC, Lee JS (2013) Physiological functionality of fermented pear fruitlet product made by mixed fermentation of Saccharomyces cerevisiae, Kluyveromyces fragilis and Lactobacillus plantarum. Korean J Mycol, 41, 33-37

35. Yang M, Kwak JS, Jang S, Jia Y, Park IS (2013) Antioxidant activity of soybean yogurt added tomato extract by Bacillus subtilis and Lactobacillus plantarum. Korean J Food Nutr, 26, 280-286

36. Considine RV, Sinha MK, Heiman ML, Kriauciunas A, Stephens TW, Nyce MR, Ohannesian JP, Marco CC, McKee LJ, Bauer TL (1996) Serum immunoreactive-leptin concentrations in normal-weight and obese humans. $\mathrm{N}$ Engl J Med, 334, 292-295 
37. Stivam GP (2001) Protection against Helicobacter pylori and other bacterial infections by garlic. J Nutr, 1321, 1106S-1108S

38. Ahn YM, Lim SJ, Han HK, Choi SS (2006) Effects of Allium vegetable intake on levels of plasma glucose, lipid and minerals in streptozotocin induced diabetic rats. Korean J Nutr, 39, 433-443

39. Kim MJ, Ahn JH, Choi KH, Lee YH, Woo GJ, Hong EK, Chung YS (2006) Effects of pine needle extract oil on blood glucose and serum insulin levels in $d b / d b$ mice.

J Korean Soc Food Sci Nutr, 35, 321-327

40. Han CK, Kim SS, Choi SY, Park JH. Lee BH (2009) Effects of rice added with mulberry leaves and fruit on blood glucose, body fat and serum lipid levels in rats. J Korean Soc Food Sci Nutr, 38, 1336-1341

41. Lee YR, Woo KS, Hwang IG, Kim HY, Lee SH, Kim YB, Lee JS, Jeong HS (2012) Anti-diabetic activity of germinated Ilpum rough rice extract supplement in mice. J Korean Soc Food Sci Nutr, 41, 339-344

42. Stancoven A, McGuire DK (2007) Preventing macrovascular complications in type 2 diabetes mellitus: glucose control and beyond. Am J Cardiol, 99, 5H-11H

43. Gerich JE (2003) Clinical significance, pathogenesis, and management of postprandial hyperglycemia. Arch Intern Med, 163, 1306-1316

44. Hanefed M, Temelkova-Kurktschiev T (2002) Control of post-prandial and hyperglycemia-an essential part of good diabetes treatment and prevention of cardiovascular complications. Nutr Metab Cardiovasc Dis, 12, 98-107

45. Nathan DM, Singer DE, Godine JE, Harrington $\mathrm{CH}$, Perlmuter LC (1986) Retinopathy in older type II diabetics association with glucose control. Diabetes, 35, 797-801

46. Alberti KG, Zimmet P, Shaw J (2005) The metabolic syndrome-a new world-side definition : IDF epidemiology task force consensus group. Lancet, 366, 1059-1062

47. Despres, JP, Lamarche B, Mauriege P, Cantin B, Dagenais GR, Moorjani S, Lupien PJ (1996) Hyperinsulinemia as an independant risk factor for ischemic heart disease. N Engl J Med, 334, 952-957

48. Seifarth C, Bergmann J, Holst JJ, Ritzel R, Schmiegel W, Nauck MA (1998) Prolonged and enhanced secretion of glucagon-like peptide 1 (7-36 amide) after oral sucrose due to alpha-glucosidase inhibition (acarbose) in type 2 diabetic patients. Diabet Med, 15, 485-491

49. Sandhu H, Wiesenthal S, MacDonald PE, McCall RH, Tchipashvili V, Rashid S, Satkunarajah M, Irwin DM, Shi ZQ, Brubaker PL, Wheeler MB, Vranic M, Efendic S, Giacca A (1999) Glucagon-like peptide-1 increases insulin sensitivity in depancreatized dogs. Diabetes, 48, 1045-1053

50. Trumper K, Trumper A, Trusheim H, Arnold R, Goke B, Horsch D (2000) Integrative mitogenic role of protein kinase B/Akt in beta-cells. Ann NY Acad Sci, 921, $242-250$ 